Rok XVI (2021) | 1 (31) | S. 289-291

https://doi.org/10.12797/LV.16.2021.31.24

Licencja: CC BY-NC-ND 4.0

Maciej Rak (๑)

Uniwersytet Jagielloński, Kraków

maciej.rak@uj.edu.pl

\title{
WKŁAD PROFESORA BOGUSŁAWA DUNAJA DO POLSKIEGO JĘZYKOZNAWSTWA
}

Rocznica osiemdziesiątych urodzin (4 IX 2020 r.) Profesora Bogusława Dunaja, nierozerwalnie związanego i kojarzonego z Uniwersytetem Jagiellońskim i innymi instytucjami naukowymi (m.in. Towarzystwem Miłośników Języka Polskiego, Polskim Towarzystwem Językoznawczym, Radą Języka Polskiego i Komitetem Językoznawstwa PAN), skłania tych, którzy są Jego uczniami albo uczniami Jego uczniów (należę do tej właśnie grupy) do refleksji. Nie będę przybliżał życiorysu Jubilata, zrobiła to bowiem przed jedenastu laty Janina Labocha (2010). Nie będę też szczegółowo charakteryzował Jego dorobku naukowego i dydaktycznego, gdyż możemy o tym przeczytać zarówno w książce Symbolae grammaticae in honorem Boguslai Dunaj (Przybylska, Kąś, Sikora 2010), jak i na stronie internetowej Katedry Historii Języka i Dialektologii Wydziału Polonistyki UJ ${ }^{1}$, której Profesor był kierownikiem w latach 1978-2010. W tym tekście chciałbym zwrócić uwagę na to, co z perspektywy średniego pokolenia językoznawców zawdzięczamy Bogusławowi Dunajowi.

Jubilat ma bardzo duży wkład w badania historycznojęzykowe. Podczas studiów (w latach 1958-1963) wiedzę z tego zakresu zdobywał u Zenona Klemensiewicza, Witolda Taszyckiego, Mieczysława Karasia i Ewy Ostrowskiej. Szczególne miejsce wśród Jego prac historycznojęzykowych zajmują trzy książki: Wzdłużenie zastępcze w języku polskim (1966), Iteratiwa typu bierać, pisywać w języku polskim (1971) oraz Język polski najstarszej doby piśmiennej (XII-XIII w.) (1975). Są to kolejno -

http://www.dialektologia.polonistyka.uj.edu.pl/pracownicy/prof.-dr-hab.-boguslaw-dunaj. 
magisterium (napisane pod kierunkiem M. Karasia), doktorat (przygotowany również pod kierunkiem Karasia) i habilitacja. Badania historycznojęzykowe Bogusław Dunaj z różnym natężeniem prowadzi właściwie do dziś, czyli przez niemal 60 lat. Przed jedenastu laty zorganizował wraz z pracownikami swojej katedry konferencję, z której materiały ukazały się jako monografia zbiorowa Badania historycznojęzykowe. Stan, metodologia, perspektywy (Dunaj, Rak 2011), a obecnie przygotowuje książkę dotyczącą kształtowania się polskiego języka literackiego (jej planowany druk to 2021 r.). Pod Jego opieką doktoraty z zakresu historii języka uzyskały Sylwia Przęczek-Kisielak i Zofia Zając-Gardeła.

Pod koniec lat 70. zeszłego wieku Bogusław Dunaj zmienił profil swoich badań, co zostało spowodowane przedwczesną śmiercią (w 1977 r.) M. Karasia. Wówczas Jubilat niejako z konieczności przejął po swoim mistrzu koordynację prac nad polszczyzną mówioną Krakowa (dokładniej był to problem węzłowy Język mówiony Krakowa i Nowej Huty), w pewnym zakresie kontynuowanych do dziś (Dunaj 2019). Po latach powrócił do tego zagadnienia, organizując konferencję Polszczyzna mówiona ogólna i regionalna, której materiały wyszły w 2009 r. pod takim samym tytułem (Dunaj, Rak 2009). Przy okazji badań nad językiem mówionym doktoraty uzyskali niektórzy spośród Jego uczniów: Maria Madejowa, Janina Labocha, Halina Kurek, Józef Kąś, Kazimierz Ożóg i Krystyna Data.

Profesor Bogusław Dunaj był także prekursorem krakowskiej socjolingwistyki, którą później twórczo rozwijali H. Kurek i J. Kąś. Zresztą badania tego typu są kontynuowane do dziś w Katedrze Lingwistyki Kulturowej i Socjolingwistyki WP UJ. Z tego zakresu do klasycznych prac Jubilata, które weszły do literatury socjolingwistycznej i są cytowane, należy artykuł Dialektologia a socjolingwistyka (Dunaj 1986). Oczywiście prowadził On też badania dialektologiczne (przez kilkadziesiąt lat był opiekunem studenckiego koła dialektologicznego) i promował doktoraty $\mathrm{z}$ tego zakresu - pod Jego opieką stopień naukowy doktora uzyskali: Krystyna Kiernożycka, Kazimierz Sikora i Anna Kostecka-Sadowa.

Osobnym nurtem badań Profesora jest współczesna polszczyzna ujmowana z różnych perspektyw - regionalizmów i poprawności językowej (tu mieszczą się współautorskie artykuły z Mirosławą Mycawką), a także leksykograficznej. Dzięki inicjatywie Bogusława Dunaja w polskiej leksykografii mówi się nie tylko o słownikach wileńskim i warszawskim, ale także o krakowskim, tak bowiem czasem jest skrótowo nazywany zredagowany przez Niego Słownik współczesnego języka polskiego (SWJP). Pomysły wypracowane w zespole słownikowym, do którego należeli m.in.: Bogusław Dunaj, Józef Kąś, Mirosława Mycawka, Renata Przybylska i Kazimierz Sikora, twórczo wykorzystał - co wielokrotnie podkreślał - J. Kąś w Słowniku gwary orawskiej (KąśSGO) i Ilustrowanym leksykonie gwary i kultury podhalańskiej (KąślLG). W zakresie badań nad współczesną polszczyzną doktoraty przygotowali następujący uczniowie Jubilata: Renata Przybylska, Donata Ochmann, Monika Buława i Barbara Batko-Tokarz. 
Z tego wszystkiego, co napisałem wyżej, z przywołanych publikacji i nazwisk uczniów Profesora Bogusława Dunaja, spośród których część jest profesorami i pracuje w innych ośrodkach niż Uniwersytet Jagielloński, wyłania się obraz szkoły naukowej. Nie ma ona co prawda ściśle określonego profilu tematycznego i metodologicznego (jak to zwykle bywa z tego typu szkołami), ale to dlatego, że umysłowość i zainteresowania naukowe Jubilata zawsze były bardzo szerokie.

Osiemdziesiąte urodziny to wspaniały jubileusz. Ważne dla nas, uczniów i współpracowników Bogusława Dunaja, jest to, że zawsze możemy liczyć na Jego rady naukowe i że wciąż zaskakuje nas ciekawymi, pobudzającymi do badań i dyskusji pomysłami, referatami i publikacjami.

\section{Literatura}

Dunaj B., 1966, Wzdtużenie zastępcze w języku polskim, „Zeszyty Naukowe Uniwersytetu Jagiellońskiego”, „Prace Językoznawcze”, nr 17, Kraków.

DunAJ B., 1971, Iteratiwa typu bierać, pisywać w języku polskim, „Zeszyty Naukowe Uniwersytetu Jagiellońskiego”, „Prace Językoznawcze”, nr 32, Kraków.

Dunaj B., 1975, Język polski najstarszej doby piśmiennej (XII-XIII w.), „Zeszyty Naukowe Uniwersytetu Jagiellońskiego”, „Prace Językoznawcze”, nr 45, Kraków.

Duna B., 1986, Dialektologia a socjolingwistyka, „Acta Universitatis Lodziensis. Folia Linguistica" 12, s. 15-23.

Dunaj B., 2019, Badania polszczyzny krakowskiej - przeszłość i teraźniejszość, „LingVaria” nr 14 (27), s. 35-47, [on-line:] https://doi.org/10.12797/LV.14.2019.27.02.

Dunaj B., RaK M. (red.), 2009, Polszczyzna mówiona ogólna i regionalna. Materiały ogólnopolskiej konferencji naukowej, Kraków 25-26 września 2008 r., „Biblioteka LingVariów”, t. 5, Kraków.

Dunaj B., Rak M. (red.), 2011, Badania historycznojęzykowe. Stan, metodologia, perspektywy. Materiały konferencji naukowej, Kraków 21-22 września 2010 r., „Biblioteka LingVariów", t. 14, Kraków.

KąśILG: J. Kąś, Ilustrowany leksykon gwary i kultury podhalańskiej, t. I: A-B, Bukowina Tatrzańska - Nowy Sącz - Nowy Targ 2015, t. II: C-Do, Bukowina Tatrzańska - Nowy Sącz - Nowy Targ 2015, t. III: Dó-Gr, Bukowina Tatrzańska - Nowy Targ 2016, t. IV: Gu-Kol, Kraków 2017, t. V: Kot-Mad, Nowy Sącz 2017, t. VI: Maf-Nie, Nowy Sącz 2018, t. VII: Nif-Pap, Nowy Sącz 2018, t. VIII: Par-Pou, Nowy Sącz 2018, t. IX: Pow-Sce, Nowy Sącz 2019, t. X: Sch-Śró, Nowy Sącz 2019, t. XI: Śry-Wych, Nowy Sącz 2019, t. XII: Wyci-Ż, Nowy Sącz 2019.

KąśSGO: J. Kąś, Słownik gwary orawskiej, Kraków 2003.

Laвосна J., 2010, Profesor Bogusław Dunaj. Mistrz, Nauczyciel, Kolega, [w:] R. Przybylska, J. Kąś, K. Sikora (red.), Symbolae grammaticae in honorem Boguslai Dunaj, „Biblioteka LingVariów", t. 9, Kraków, s. 9-12.

Przybylska R., Kąś J., Sikora K. (red.), 2010, Symbolae grammaticae in honorem Boguslai Dunaj, „Biblioteka LingVariów”, t. 9, Kraków.

SWJP: B. Dunaj (red.), Słownik współczesnego języka polskiego, Warszawa 1996. 